\title{
Insect-based protein feed: from fork to farm ${ }^{1}$
}

\author{
H. Jensen, C. Elleby" (D), I.P. Domínguez (iD, T. Chatzopoulos iD) and P. Charlebois \\ European Commission, Joint Research Centre, C/ Inca Garcilaso 3, Seville, 41092, Spain; christian.elleby@ec.europa.eu
}

Received: 18 January 2021 / Accepted: 22 Mar 2021

(c) 2021 Wageningen Academic Publishers

OPEN ACCESS @ (1) RESEARCH ARTICLE

\begin{abstract}
Numerous studies show that insects are efficient in converting organic waste into proteins and fats, which makes them an interesting alternative source of feed. Moreover, since around one-third of global food produced for human consumption is lost or wasted, the production of insect-based meals from food waste is considered a sustainable alternative to other protein sources. This paper introduces a quantitative framework able to analyse the economic implications of developing a large-scale insect-based meal industry worldwide, which would require important regulatory changes. Our calculations, based on findings from the literature, suggest that almost 1.4 billion tonnes of food, that could potentially be used as insect feed, went to waste at the world level in 2018, a figure that is projected to rise to 2 billion tonnes by 2030. Results show that the use of food waste for insect meal and oil production would have important downward price impacts on meals and oils (fish- and plant-based), reducing feed costs and stimulating global aquaculture and livestock production, reducing total land use for agriculture production and lead to a lower dependence on protein imports.
\end{abstract}

Keywords: insect-based meals, protein feed markets, aquaculture, protein self-sufficiency, partial equilibrium model

\section{Introduction}

The United Nations (UN) estimates that the global population will increase by 2 billion persons in the next 30 years, adding further pressure on natural resources to meet the growing demand for food (UN, 2019). Given the constrained availability of resources and changing climate, food security can only be achieved by deploying more sustainable and efficient production systems (IPCC, 2019). One important contribution to attaining this goal is to increase the efficiency of the entire food supply chain 'from farm to fork', which includes reducing the amount of food waste. The UN in its $12^{\text {th }}$ Sustainable Development Goal (SDG) highlights this: 'Ensure sustainable consumption and production patterns' (UN, 2015). Specifically, SDG target 12.3 refers to food waste. Target 12.5 refers to waste in general and to recycling. ${ }^{2}$
These goals are also reflected in the European Green Deal (EC, 2019, 2020) and its Farm to Fork Strategy (F2F), in which the transition towards a sustainable food chain is a key objective. The F2F envisions a circular biobased economy with bio-refineries creating new jobs and contributing to a lower climate footprint of the farming sector through the production of bio-fertilisers, protein feeds, bioenergy and bio-chemicals. It also mentions that the Commission will examine EU rules to reduce the dependency of the livestock sector on imported soybeans by fostering additional production of domestically grown plant protein as well as alternative feed materials including insects and by-products such as fish waste (EC, 2020: 10). ${ }^{3}$ In this context, the insect farming industry could play an important role in closing the loop 'from fork to farm', by transforming food losses and waste into an additional supply of protein feed for livestock and aquaculture. This would

\footnotetext{
${ }^{1}$ The opinions expressed and arguments employed herein are those of the authors and do not necessarily reflect the official views of the European Commission.

${ }^{2}$ Target 12.3: 'By 2030, halve per capita global food waste at the retail and consumer levels and reduce food losses along production and supply chains, including post-harvest losses.' Target 12.5: 'By 2030, substantially reduce waste generation through prevention, reduction, recycling and reuse.' ${ }^{3}$ See also EC (2018).
} 
imply reintroducing nutrients back into the food chain, substantially reducing waste through recycling.

The insect farming industry is already present in Europe today producing more than 5,000 tonnes of insect protein for pet foods and aquaculture feed on by-products from the agri-food industry (IPIFF, 2019). The industry is expanding with increasing investments in new industrial size insect farms. Moreover, there is a strong demand for 'green' policies and several regulatory agencies around the world are evaluating the potential for insect production on an industrial scale. There are several publicly funded research projects looking into the issue as well (Kupferschmidt, 2015). Given the potential contribution insect farming could have in reaching the SDG of reducing food waste, this paper analyses how a large expansion of this industry will affect global agricultural markets and the greenhouse gas (GHG) emissions associated with agricultural production.

Specifically, we analyse three scenarios using the OECDFAO Aglink-Cosimo model of the global agricultural markets and the FAO FISH Model. In the first scenario, all available global food waste is converted into insect protein meal (ITM) and insect oil (ITL), and utilised in the agricultural and aquaculture sectors. The second scenario is more moderate since only $50 \%$ of the total food waste is recycled, with the resulting protein being fed to both livestock and aquaculture production activities, as in the previous scenario. Last, but not least, a third scenario contemplates a more restrictive situation where ITM is only utilised in the aquaculture sector requiring $21 \%$ of the total available food waste to be recycled.

After this introductory section, the paper first gives an overview of the insect farming industry and the current regulatory environment. It then provides a calculation of the globally available food waste, followed by a description of the analytical framework and the scenarios considered in the analysis. Finally, the main results are discussed and some limitations of the study highlighted.

\section{Insects, closing the loop from farm to fork}

The main reason why insects are an interesting source of food and feed is that they are able to connect the agricultural supply chains and improve the circularity of the bio-economy. Around one-third of all food produced for human consumption is lost or wasted globally according to the Food and Agricultural Organization of the United Nations (FAO, 2011). While this estimate is subject to considerable uncertainty, there is no doubt that large quantities of food go to waste every year and only few options are available for reutilisation. One option, which has received considerable interest recently, is to recycle wasted food through insect bioconversion into protein feed used in the livestock and aquaculture sectors (Barbi et al., 2020; Dicke, 2018; Dobermann et al., 2017; Ganda et al., 2019; Govorushko, 2019; St-Hilaire et al., 2007; Stamer, 2015; Tao and Li, 2018).

Insects have the ability to convert organic waste into proteins and fat at a high conversion rate (Van Broekhoven et al., 2015). The protein and part of the fat can be utilised directly in the feed industry and the rest of the fat has further uses in the biofuel and other processing industries (Fowles and Nansen, 2020; Li et al., 2011; ManzanoAgugliaro et al., 2012; Wang et al., 2017; Zheng et al., 2012). However, in most countries, there is a regulation in place, which prevents large-scale production of insects for food and feed use (Lähteenmäki-Uutela and Grmelová, 2016; Lotta, 2019; Pinotti et al., 2019).

The use of food waste as animal feed has been a common practice for centuries. However, the practice of feeding food waste to animals has declined rapidly since the 1980s when there were several disease outbreaks linked to animal feed, including foot-and-mouth and transmissible spongiform encephalopathy. In an attempt to prevent the spread of such diseases, many governments around the world have passed regulations that restrict the use of food waste in animal feed. In the EU, for example, a ban of mammalian processed animal protein (PAP) fed to cattle, sheep and goats was introduced in 1994. The ban was expanded in January 2001 with the feeding of all processed animal proteins to all farmed animals being prohibited, with certain limited exceptions. ${ }^{4}$ This is to ensure that there is no cross-contamination between feed containing PAP intended for non-ruminants and feed intended for ruminants. In 2015 the European Food Safety Authority (EFSA) published a scientific opinion discussing the risks associated with insect based feed (EFSA Scientific Committee, 2015). Based on this opinion ITM were approved for use in aquaculture feed within the EU in $2017 .^{5}$

Insects produced in the EU for food, feed or other purposes are considered 'farmed animals' and are therefore covered by the rules restricting the types of feed they may be given. Consequently, farmed insects may only feed on materials of vegetable origins, with some exceptions on milk, eggs and other products of animal origins. Moreover, EU regulation requires producers to keep their animals in good health and this applies to insect producers as well. Invertebrates,

\footnotetext{
${ }^{4}$ Regulation EC No. 999/2001 (EC, 2001).

${ }^{5}$ Commission Regulation (EU) 2017/893 (EC, 2017).
} 
including insects, are exempted from regulation in the area of animal welfare though (IPIFF, 2020).

Many insect species can be used for protein production, including the larvae of the black soldier fly (BSF) (Hermetia illucens), the common housefly (Musca domestica), the yellow mealworm (Tenebrio molitor) as well as blue bottle (Calliphora vomitoria) and blow flies (Chrysomya spp.). Among those, the most promising in terms of food-waste recycling is the BSF (Oonincx et al., 2015; Veldkamp and Bosch, 2015). The BSF is neither a pest nor a disease vector and its larvae are omnivorous and very robust against diseases (Nguyen et al., 2015; Purschke et al., 2017). Originating from the southern states of USA, BSF now occurs worldwide in all tropical, warm and moderate climate zones due to the shipping from continent to continent. Fully-grown larvae produce a biomass that contains $40-45 \%$ protein with an advantageous amino acid composition and up to $35 \%$ fat in dry matter, which makes it suitable as a feed supplement for various animals (Barragan-Fonseca et al., 2017; Schiavone et al., 2017). Meal from BSF larvae have a protein content that is similar to defatted soybean meal but the fat content is well above the fat content of fish meal (FM). Because the fatty acid profile of BSF meal is suboptimal for feed purposes, the oil must be extracted from the biomass before it is processed. It has been shown that extracted insect oil meets most of the requirements set by the international standard EN 14214 for biodiesel (Nguyen et al., 2018). ITL processed into biodiesel is therefore potentially an important by-product from protein feed based on the BSF larvae.

In addition to regulatory and production issues affecting supply, the arrival of an insect feed industry depends on demand factors. The main question is whether insect meal can be introduced in the feed diet of the different animals without affecting the feed conversion, the taste and the quality of the products. Different studies support the fact that insect meals will be easier to introduce in the diet of aquaculture species, followed by poultry, and in particular, laying hens (Belghit et al., 2018; Gariglio et al., 2019; Heuel et al., 2019; Iaconisi et al., 2017; Magalhães et al., 2017; Makkar et al., 2014; Maurer et al., 2016; Sealey et al., 2011; Veldkamp et al., 2012).

\section{From food waste to insect-based protein meal}

Estimating the amount of food that goes to waste every year along the food chain at the global or regional level is not an easy task and only a few studies attempt to do it (Caldeira et al., 2019; FAO, 2011, 2019). Amongst them, the most comprehensive reference in the literature is FAO (2011). This study considers seven geographical areas and seven agricultural and fish products that are wasted or lost throughout five stages of the food chain: agricultural production; post-harvest handling and storage; processing; distribution; consumption. ${ }^{6}$

Since in our ex-ante analysis we consider market developments until 2030, food loss percentages in FAO (2011) have been extrapolated based on the positive relationship between per capita GDP and food waste in the consumption stage of the food chain. Conversely, in the processing and packaging as well as in the distribution stages of the chain, there is a negative relationship between food waste and per capita income has been used as the basis for extrapolation. Only in the agricultural production and post-harvest stages no correlation is assumed between food waste and per capita income, so that the same estimates are used in all years.

The food waste available for insect feeding is assumed to come from the production, processing, distribution and consumption of root, tubers, fruits and vegetable, pulses, eggs, meat, fish, sugar, cereals and dairy products. In the technical annex, a detailed description of the approach used to calculate the amount of food waste available for insect production in each stage of the supply chain is provided. It involves an assessment of the amounts available of each commodity in each of the stages after accounting for byproducts. The general formula used to calculate the waste available for insect production is as follows:

$$
\begin{aligned}
\text { Waste }_{i, r} & =Q P_{i, r} \times \frac{S H R_{1, i, r}}{1-S H R_{1, i, r}} \\
& +Q C_{i, r} \times\left(S H R_{3, i, r}+\left(1-S H R_{3, i, r}\right) \times S H R_{4, i, r}\right. \\
& \left.+\left(1-S H R_{3, i, r}\right) \times\left(1-S H R_{4, i, r}\right) \times S H R_{5, i, r}\right)- \text { BPFeed }_{i, r}
\end{aligned}
$$

where $\mathrm{i}$ and $\mathrm{r}$ are the commodity and country indices, respectively. $Q P_{i, r}$ denotes production, $Q C_{i, r}$ consumption, $S H R_{s, i, r}$ is the waste share in the different stages and BPFeed $_{i, r}$ denotes by-product feed (see paragraph below).

To calculate the amount of fruits and vegetables (FV) waste available for insect feed, for example, we start with $Q P_{F V, r}$ and subtract the loss occurring in stage 1 (agricultural production) due to mechanical damage or spillage during harvest operations. Losses occurring in stage 2 (post-harvest handling and storage) are not included since degradation

\footnotetext{
${ }^{6}$ The report distinguishes between food loss and food waste. The former refers to losses occurring in the parts of the supply chain that leads to food for human consumption, i.e. the production, post-harvest and processing stages. Food waste, on the other hand, refers to losses occurring in the final stages of the supply chain, i.e. in connection with distribution and consumption (Parfitt et al., 2010). In the present paper, the term food waste refers to losses occurring in all stages of the food chain. The food waste percentages in FAO (2011) do not include sugar beets and eggs, so for these commodities we supplement with food loss percentages calculated from Table 1 in Caldeira et al. (2019).
} 
during handling, storage and transport from the farm would probably leave the product in a sufficiently good state to be directly used as feed. Waste occurring in stages 3 to 5 (processing, distribution and consumption) is calculated using the total consumption of FV, which includes waste. Finally, some by-products already being used as animal feed (for example distillers grains with solubles (DDGS), molasses, meat and bone meal, etc.) are deducted from the total amount of waste available for insect production.

In order to calculate the amount of insect meal that can be produced from food waste information on the feed conversion ratio (FCR) is needed. Salomone et al. (2017) report that with one tonne of food waste $29.6 \mathrm{~kg}$ of dry larvae with $42 \%$ protein and $35 \%$ crude fat could be produced. The protein content is similar to defatted soybean meal (48\%) but the fat content is well above the fat content of FM (around 14\%). Since insect meal is considered to be a good replacement of FM and oilseed meal used in aquaculture and in the first feeding phase of poultry and pigs, we assume that the extra fat (i.e. from 35 to $14 \%$ ) will be extracted and used in the biodiesel industry rather than in the feed system. With this extraction the percentage of protein will increase to $53 \%$ which is much closer to the typical percentage of protein in FM.

The numbers reported by Salomone et al. (2017) corresponds to an FCR of 33.8 on a dry weight (DW) basis or 12.7 on a wet weight (WW) basis (assuming a water content of $62.3 \%$ ). This is in line with other estimates found in the literature. Danieli et al. (2019), for example, report WW FCRs of 13.1-19.2, depending on the diet given to the BSFs. There are, however, also examples in the literature of much lower FCRs, implying a higher feed efficiency (e.g. Banks et al., 2014). The choice of FCR has a large effect on the scenario results and we therefore stick to a fairly conservative estimate of the FCR estimated by Salomone et al. (2017), which is used universally across all countries and commodities found in this analysis.

With these assumptions, our calculations suggest that almost 1.4 billion tonnes of food, that could potentially be used as insect feed, were wasted at the world level in 2018. This could increase to 2 billion tonnes by 2030 with waste originating from: fruit and vegetables $63 \%$, cereals $20 \%$, other crops $5 \%$, meat and dairy $7 \%$ and fish $5 \%$. The large share of fruits and vegetables in total food waste is partly due to the large amounts produced together with a high waste percentage due to the perishability of the product, and partly a result of our assumptions regarding the economic feasibility of recuperating the wasted fruit and vegetables at the production level.

In the EU, about 129 million tonnes of food waste will be available, in principle, for insect meal production in 2030, according to our calculations. If this was used as insect feed, the EU would be able to produce around 3 million tonnes of insect meal and 0.8 million tonnes of insect oil by 2030 (Figure 1 and 2), which is in line with the reported estimates by IPIFF (2019).

\section{Analytical framework}

\section{The model and the baseline}

The analysis in this paper is based on the Aglink-Cosimo model and the associated OECD-FAO Agricultural Outlook database ${ }^{7}$. Aglink-Cosimo is a recursive-dynamic multicommodity model of global agriculture and includes projections of agricultural markets until 2030 (Araujo Enciso et al., 2015; OECD, 2015), what we refer to as the medium-term outlook (MTO) or 'baseline'.

For this analysis, we modified the standard version of Aglink-Cosimo to include the FV sector and an ITM and ITL industry producing high protein feed from BSF larvae in all countries. Insect farming is assumed to be entirely based on food waste, with a large proportion coming from FV and FV by-products. ${ }^{8}$ This includes the amounts of wasted material in each part of the supply chain for each of the agricultural commodities. The amount of food waste feed to the BSF larvae is exogenously phased in over the baseline period using a homogenous feed conversion ratio across all countries (Salomone et al., 2017). The amount of insectbased meals (ITM) and insect-based oils (ITL) produced are simply added to the aggregated vegetable protein meal (PM) and the vegetable oils (VL) production already present in the Aglink-Cosimo model. This modelling approach implies that insect meals and oils are perfect substitutes of vegetable meals and oil. In the present Aglink-Cosimo model, market-clearing prices for vegetable meals and oils are endogenously determined. As the amount of waste fed to the BSF larvae is phased in, market mechanisms (i.e. supply, demand and the equilibrium condition) reduce the price of vegetable meals and oil. In our modelling approach, it is assumed that insect meals and oil are price takers, with their prices being equal to the market-clearing price of vegetable meals and oil.

This assumption is of course linked to the fact that we are exogenously (outside of the model) deciding the level of production through how much waste is utilised by the insect farming industry. To change this assumption would require us to estimate an ITM production function requiring own price elasticities as well as cross price elasticities with regard to the price of soya meal, rape meal, sunflower meal, fish meal, etc. combined with waste price elasticities and possibly

\footnotetext{
${ }^{7}$ www.agri-outlook.org.

${ }^{8}$ More detailed explanations are presented in the technical annex; Supplementary Material S1.
} 


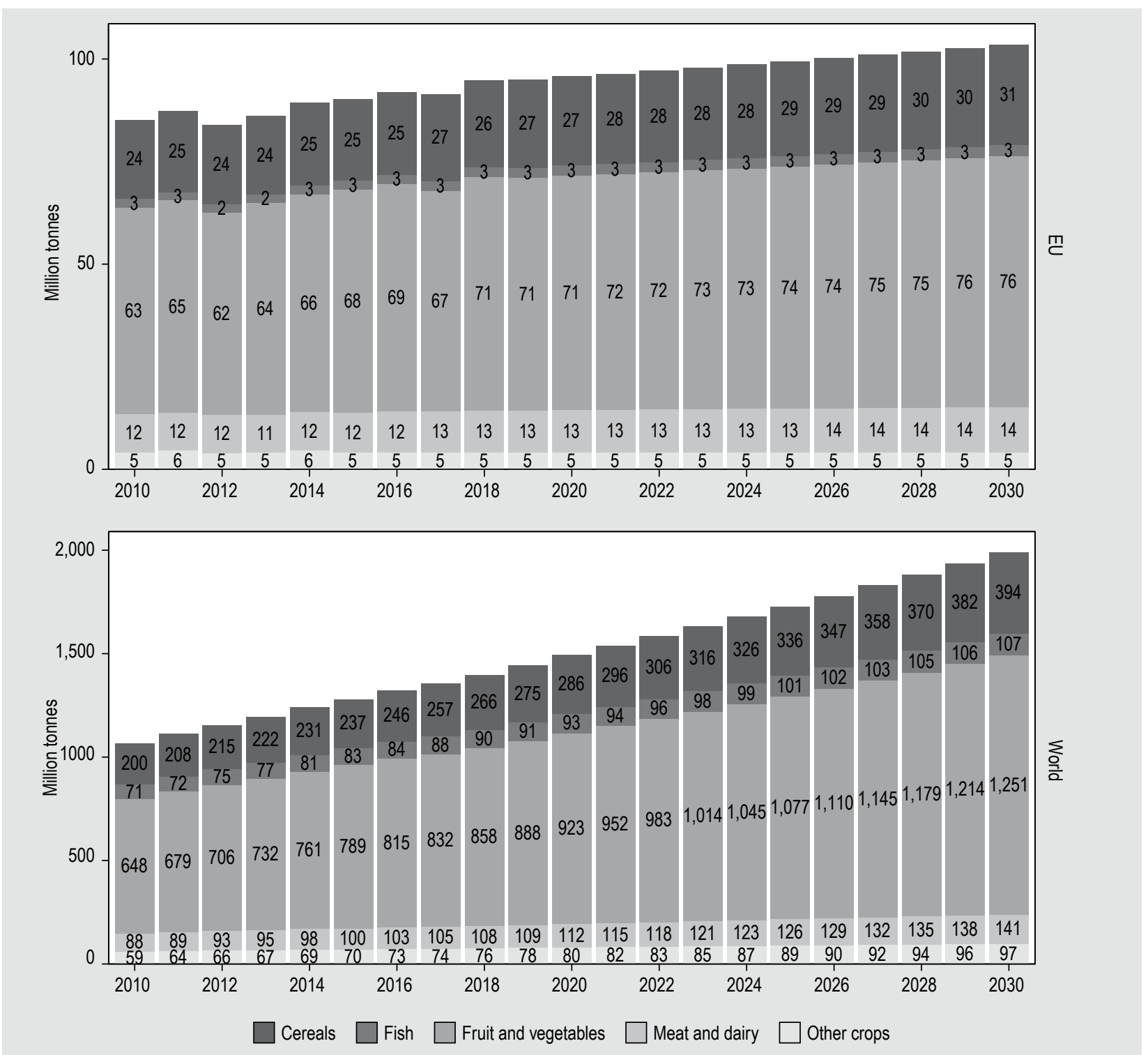

Figure 1. Food waste by commodity group, 2010-2030.

elasticities linked to size of animal production. Then the question of market clearing prices of waste and own prices would have to be specified. This is beyond the scope of this paper given the global coverage of the Aglink-Cosimo model. Instead we span a range of waste utilised in the BSF larva farming industry in three scenarios to highlight the impact this could have on agricultural and aquaculture markets.

Additional to Aglink-Cosimo, the fisheries and seafood sectors are covered by the FISH model, a model developed and maintained by the FAO (OECD/FAO, 2020). This model is used to produce a global fisheries outlook and contributes on a yearly basis to the OECD-FAO agricultural outlook with a chapter on fisheries for which it formally interacts with the Aglink-Cosimo model for consistency purposes (e.g. alignment of short to medium-term macroeconomic developments). On the supply side, the FISH model distinguishes between fish from capture fisheries and aquaculture. Fish commodities are used for food consumption, feed processing (meals and oils) and bait. FM demand responds to the size of the aquaculture sector and prices of the different protein meals. For this paper, the AglinkCosimo and the FISH models were used simultaneously.

The FISH model suffers from three main limitations. First, the model assumes that countries for which the fishmeal production is based on controlled capture (i.e. fish quotas), production does not react to prices and only to the El NiñoSouthern Oscillation (ENSO) cycle. Second, the model only has a single representative aquaculture price per country used for all the individual aquaculture species. Third, the model has a limited ability to capture the effect of the 'fishmeal trap' (i.e. lower availability of fishmeal due to the strict controls on capture fisheries and the rapid growth 


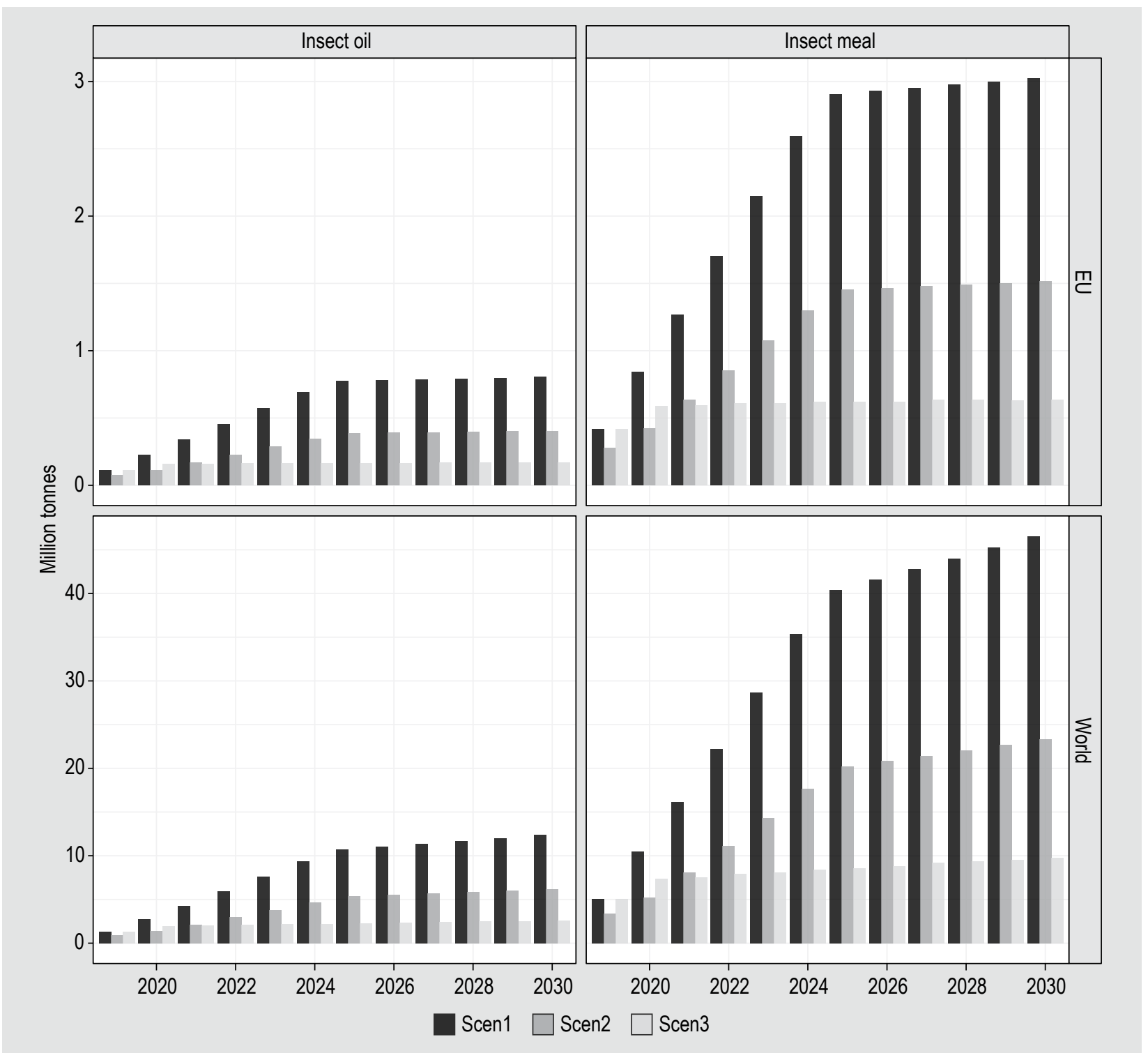

Figure 2. Global insect meal and insect oil production in the three scenarios.

in aquaculture production creating a premium price for fish meal compared to oilseed meals) on the FM to oilseed meal price ratio. Since ITM might be more appropriate than oilseed meal in the feed ration of many aquaculture species, part of this price gap between FM and oilseed meal could be eliminated with the market expansion of ITM ${ }^{9}$.

\section{Scenarios}

We construct three counterfactual scenarios to the baseline, denoted Scen1, Scen2 and Scen3, in order to analyse the additional supply of protein feed and the oil by-product produced from insects fed on food waste. The scenarios differ with respect to the availability of food waste to feed

\footnotetext{
${ }^{9}$ See the section of the fishmeal trap in the technical annex; Supplementary Material S1.
}

the insect farming sector (supply side) and the possibility to feed non-ruminant livestock and aquaculture species (regulatory side). Table 1 summarises these differences.

Scen 1 is the most extreme of these scenarios in the sense that there are no restrictions on the use of ITM as feed in any of the livestock sectors. In addition, we assume that the ITM input costs (i.e. cost of recycling waste) are low enough and the revenue obtained from sales of byproduct from ITM production makes ITM so competitive to other protein meals that it is profitable to use the entire amount of available food waste to produce ITM. In Scen2, it is assumed that turning food waste into feed for insects shows an upward marginal cost curve with a steeper slope than in Scen 1 and therefore only $50 \%$ of the total amount of available food waste used for ITM production can be competitive. There are no restrictions, however, on the use of ITM feed in the livestock sector in this scenario. Finally, 
Table 1. Comparison of the three scenarios.

$\begin{array}{llll} & \text { Scen1 } & \text { Scen2 } & \text { Scen3 } \\ \begin{array}{llll}\text { Share of food waste used } \\ \text { to produce insects }\end{array} & 100 \% & 50 \% & 21 \% \\ \begin{array}{c}\text { Demand for insect meal } \\ \text { all livestock } \\ \text { sectors }\end{array} & \begin{array}{c}\text { all livestock } \\ \text { sectors }\end{array} & \begin{array}{c}\text { only aqua- } \\ \text { culture }\end{array}\end{array}$

in Scen3 it is assumed that insect meal is only allowed to be fed to aquatic animals and as a result the size of this new industry is determined by the demand coming from aquaculture. For that reason, in this scenario the demand for oilseed meal coming from aquaculture is replaced by ITM, which is assumed to be a better adapted feed ingredient for aquaculture species. Compared to the two supply scenarios (Scen1, Scen2) where we utilise 100 and $50 \%$ of total food waste, respectively, the demand scenario (Scen3) requires the insect farming industry to recycle only $21 \%$ of global food waste to meet aquaculture feed demand.

Scen1 represents the upper limit of the potential market impacts associated with the use of ITM feed produced from food waste. It is not meant as a realistic scenario but rather as a reference point for the other two scenarios that are less extreme in their assumptions. On a weight basis, the amount of ITM produced in this scenario represents around $6 \%$ of protein meal consumption and $9 \%$ of the vegetable oil used in the production of biodiesel in the EU. At the global level, if all available food waste was recycled by insects, 46.5 million tonnes of insect meal could be produced in 2030 , corresponding to $11 \%$ of the total protein meal consumption in the baseline (without insect meal) (Figure 2). ITL production would reach 12.3 million tonnes, which is equivalent to $5 \%$ of the global vegetable oil production and $41 \%$ of the vegetable oil used for biodiesel production.

In all scenarios, the changes considered are relative to the medium-term baseline. The additional ITM and ITL production is introduced over a seven years period, with equal step in the first 6 years, reaching respectively 100 and $50 \%$ use of food waste by the year 2025 in the first two supply-driven scenarios. Finally, in all scenarios, the assumption is made that part of the price gap between FM and OM is eliminated and that the percentages of food waste feed to insects is homogenous across all countries in the model.

\section{Results}

The main impacts of an expansion of the insect farming sector on the global agricultural and fish markets are summarised in Table 2-5. Scenario results are presented for year 2030 and compared to the medium-term baseline projections. In general, impacts are largest in Scen1, followed by Scen 2 and Scen3.

Oilseed markets are heavily affected, since the price of vegetable PM competes with ITM in the feed market and VL compete with ITL in the biodiesel market. On the global level, production of traditional vegetable PM (excluding ITM), falls by around 5 and $1 \%$ in Scen 1 and Scen3, respectively, and the price falls by almost a third in Scen 1 and by $9 \%$ in Scen3. Soybean and other oilseed prices fall by 20 and 16\%, respectively, in Scen 1 and by 5 and 4\%, respectively, in Scen3. Vegetable oil prices fall by 15 and $3 \%$, respectively, in the two scenarios and the pass-through rate to the price of biodiesel is around $50 \%$. This implies that biodiesel price declines by 6.9 and $1.3 \%$, respectively, in the two scenarios

The decline in the price of oilseeds through substitution provokes a shift in land use in favour of cereals and pasture (Table 4), dragging grain prices down. This leads to a modest increase in the forest area and a decrease in the agricultural area. The lower prices will in turn exert a downwards pressure on yields (i.e. lower intensity), so that the net effect on grain production is not clear a priori. Table 2 shows that, in practice, maize production decreases slightly whereas production of other coarse grains increases. Wheat and rice production is not affected. Lower feed prices are passed on to the animal product markets through lower feed cost and higher supply. The size of the shift depends on the amount of high-protein feed in the feed ration of the different livestock. The pasture and fodder area reacts positively to ruminant production incentives and negatively to crop production incentives. In each of the three scenarios, the latter effect dominates the former so the net result is an increase in the pasture and fodder area.

In each scenario, the grain area increases and in the case of other coarse grains it increases more than production, implying a decline in yield. For soybeans and other oilseeds, on the other hand, the area decreases but production decreases even more, which also implies declining yields. In fact, as shown in Table 5 all crop yields decrease in the EU, USA and Brazil. This is the case in other countries as well, such as Canada, China, and Russia.

Ruminants consume small amounts of high-protein feed, so the price of beef and sheep meat is less affected than pork, poultry and several aquaculture species that have a large share of high-protein feed in their feed ration. In the case of salmonid and marine fish, oil is also an important ingredient of the feed ration. Since the introduction of ITM leads to a sharp decrease in the price of high-protein feed and oil, the largest supply shift comes from salmonid, marine fish and shrimp (Table 3). 
Table 2. World market impacts in 2030. Percentage difference between scenario and baseline values.

\begin{tabular}{|c|c|c|c|c|c|c|}
\hline & \multicolumn{2}{|l|}{ Scen1 } & \multicolumn{2}{|l|}{ Scen2 } & \multicolumn{2}{|l|}{ Scen3 } \\
\hline & Price & Production & Price & Production & Price & Production \\
\hline \multicolumn{7}{|l|}{ Meat } \\
\hline Sheep & -5.6 & 0.7 & -3.1 & 0.4 & -1.9 & 0.0 \\
\hline Beef and veal & -7.5 & 0.6 & -4.0 & 0.3 & -2.2 & 0.1 \\
\hline Pork & -10.5 & 0.8 & -5.8 & 0.4 & -3.2 & 0.2 \\
\hline Poultry & -10.6 & 1.3 & -5.8 & 0.7 & -3.1 & 0.3 \\
\hline \multicolumn{7}{|l|}{ Dairy } \\
\hline Cheese & -5.8 & -0.2 & -3.1 & -0.1 & -1.6 & -0.1 \\
\hline Skim milk powder & -1.5 & -1.0 & -0.9 & -0.5 & -0.5 & -0.3 \\
\hline Whole milk powder & -4.7 & 0.5 & -2.5 & 0.2 & -1.3 & 0.1 \\
\hline Butter & -7.9 & 0.5 & -4.2 & 0.3 & -2.1 & 0.2 \\
\hline \multicolumn{7}{|l|}{ Grains and oilseeds } \\
\hline Wheat & -8.6 & 0.0 & -4.8 & 0.0 & -2.5 & 0.0 \\
\hline Maize & -8.9 & -0.2 & -4.9 & -0.1 & -2.6 & -0.1 \\
\hline Other coarse grains & -12.5 & 0.3 & -6.9 & 0.2 & -3.6 & 0.1 \\
\hline Rice & -1.8 & 0.0 & -1.1 & 0.0 & -0.6 & 0.0 \\
\hline Soybean & -19.9 & -6.0 & -10.7 & -3.2 & -5.3 & -1.5 \\
\hline Other oilseeds & -15.8 & -3.5 & -8.3 & -1.8 & -3.8 & -0.8 \\
\hline \multicolumn{7}{|l|}{ Biofuels } \\
\hline Biodiesel & -6.9 & 0.7 & -3.4 & 0.4 & -1.3 & 0.1 \\
\hline Ethanol & -3.2 & 0.2 & -1.7 & 0.1 & -0.9 & 0.1 \\
\hline \multicolumn{7}{|l|}{ Other processed products } \\
\hline Protein meal & -30.4 & 5.0 & -17.2 & 2.4 & -9.0 & 0.8 \\
\hline Protein meal excl. insect meal & & -6.1 & & -3.2 & & -1.5 \\
\hline Vegetable oil & -14.7 & 1.4 & -7.2 & 0.6 & -2.7 & 0.2 \\
\hline Vegetable oil excl. insect oil & & -3.7 & & -1.9 & & -0.9 \\
\hline Sugar & -4.4 & 0.2 & -2.4 & 0.1 & -1.3 & 0.0 \\
\hline
\end{tabular}

Table 3. World fish market impacts in 2030. Percentage difference between scenario and baseline values. Note: For all the aquatic species of this table, the price change represents total aquaculture.

\begin{tabular}{|c|c|c|c|c|c|c|}
\hline & \multicolumn{2}{|l|}{ Scen1 } & \multicolumn{2}{|l|}{ Scen2 } & \multicolumn{2}{|l|}{ Scen3 } \\
\hline & Price & Production & Price & Production & Price & Production \\
\hline Fish from aquaculture & -7.9 & 0.3 & -4.4 & 0.3 & -2.7 & 0.3 \\
\hline Fish from capture & -4.9 & -0.3 & -2.8 & -0.2 & -1.8 & -0.1 \\
\hline Fish total & -6.8 & 0.0 & -3.9 & 0.1 & -2.5 & 0.1 \\
\hline Fish oil & -6.3 & -1.5 & -1.8 & -1.0 & 1.6 & -0.7 \\
\hline Fish meal & -40.6 & -1.3 & -28.2 & -0.8 & -20.3 & -0.3 \\
\hline Other freshwater \& diadromous fish & -7.9 & 1.1 & -4.4 & 0.8 & -2.7 & 0.3 \\
\hline Tilapia & -7.9 & 0.6 & -4.4 & 0.5 & -2.7 & 0.3 \\
\hline Mollusc & -7.9 & -3.3 & -4.4 & -1.9 & -2.7 & -1.3 \\
\hline Shrimp & -7.9 & 5.7 & -4.4 & 4.0 & -2.7 & 3.9 \\
\hline Carp & -7.9 & -0.7 & -4.4 & -0.3 & -2.7 & -0.2 \\
\hline Salmonid & -7.9 & 7.1 & -4.4 & 4.2 & -2.7 & 3.0 \\
\hline Marine fish & -7.9 & 6.6 & -4.4 & 3.9 & -2.7 & 2.3 \\
\hline Other aquaculture species & -7.9 & -3.2 & -4.4 & -1.8 & -2.7 & -1.1 \\
\hline
\end{tabular}


Table 4. Global land use impacts in 2030. Difference between scenario and baseline values in percent and in $1000 \mathrm{ha}$.

\begin{tabular}{|c|c|c|c|c|c|c|}
\hline & \multicolumn{2}{|c|}{ Scen1 } & \multicolumn{2}{|c|}{ Scen2 } & \multicolumn{2}{|l|}{ Scen3 } \\
\hline & perc. & 1000 ha & perc. & 1000 ha & perc. & 1000 ha \\
\hline Forest & 0.05 & $2,076.5$ & 0.03 & $1,066.5$ & 0.01 & 514.6 \\
\hline Total agricultural area & -0.04 & $-2,076.5$ & -0.02 & $-1,066.5$ & -0.01 & -514.6 \\
\hline \multicolumn{7}{|l|}{ of which changes in } \\
\hline Pasture and fodder & 0.15 & $4,852.8$ & 0.07 & $2,414.2$ & 0.03 & $1,143.5$ \\
\hline Oilseeds & -3.57 & $-7,602.6$ & -1.87 & $-3,991.6$ & -0.86 & $-1,839.3$ \\
\hline Cereals & 0.52 & $2,822.6$ & 0.28 & $1,497.0$ & 0.12 & 676.9 \\
\hline Other crops & -0.28 & $-2,149.4$ & -0.13 & -986.1 & -0.07 & -495.7 \\
\hline
\end{tabular}

Table 5. Yield impacts in 2030. Percentage difference between scenario and baseline values.

\begin{tabular}{|c|c|c|c|c|c|c|c|c|c|}
\hline & \multicolumn{3}{|l|}{ Scen1 } & \multicolumn{3}{|l|}{ Scen2 } & \multicolumn{3}{|l|}{ Scen3 } \\
\hline & Brazil & EU & USA & Brazil & EU & USA & Brazil & EU & USA \\
\hline Barley & & -0.60 & -1.72 & & -0.32 & -0.92 & & -0.16 & -0.47 \\
\hline Maize & -0.70 & -0.42 & -0.41 & -0.38 & -0.23 & -0.22 & -0.19 & -0.12 & -0.11 \\
\hline Wheat & -2.99 & -0.43 & -0.17 & -1.63 & -0.23 & -0.09 & -0.83 & -0.12 & -0.05 \\
\hline Rice & -0.47 & -0.15 & -0.03 & -0.26 & -0.09 & -0.02 & -0.13 & -0.05 & -0.01 \\
\hline Soybean & -2.57 & -1.15 & -0.90 & -1.32 & -0.59 & -0.46 & -0.63 & -0.28 & -0.22 \\
\hline Rapeseed & & -1.15 & & & -0.58 & & & -0.25 & \\
\hline Sunflower seed & & -0.77 & & & -0.39 & & & -0.17 & \\
\hline Sugarbeet & & -0.13 & -0.64 & & -0.07 & -0.34 & & -0.04 & -0.18 \\
\hline Sugarcane & -0.51 & & -0.63 & -0.27 & & -0.34 & -0.14 & & -0.18 \\
\hline Roots and tubers & -0.45 & -0.17 & -0.08 & -0.23 & -0.09 & -0.04 & -0.12 & -0.04 & -0.02 \\
\hline Pulses & -2.05 & -1.80 & -1.81 & -1.09 & -0.96 & -0.96 & -0.56 & -0.50 & -0.50 \\
\hline Cotton & -0.17 & -0.14 & -0.03 & -0.09 & -0.08 & -0.02 & -0.04 & -0.04 & -0.01 \\
\hline
\end{tabular}

Dairy prices are also affected, which is partly caused by a fall in the feed demand for skimmed milk powder (a high-protein feed), which lowers the price of non-fat solids and, in turn, the price of other dairy products (Table 2). Moreover, the increase in milk supply caused by lower feed costs exerts further pressure on prices.

FM is a high-protein feed consumed by non-ruminants and by various aquaculture species. Depending on the scenario, ITM will replace other high-protein meals used in feed, but in the aquaculture sector specifically, it will replace FM in feed rations of aquaculture species where the content of FM is above the minimum required amount. This is mostly the case in aquaculture of the developed economies of Europe, North America, Oceania and Japan. Thailand shrimp and tilapia and Malaysia shrimp are the only three exceptions. However since fishmeal is mostly produced from controlled capture production and from waste, the addition of ITM only results in a modest decline of FM production in each of the scenarios. The inelastic supply of FM also means that the introduction of ITM as a novel source of feed proteins has a large effect on the price of FM. It reduces the demand for FM, thereby lowering the price of FM, e.g. by $28 \%$ in scen 2 (Table 3 ).

In the demand driven scenario (Scen3) the amount of waste used for insect meal production hovers around $21 \%$ in all the years. Given the assumption that the same percentages of waste are used in all countries of the model, creates a situation where production of insect meal can be smaller or greater than demand depending on the amount of waste and aquaculture production. For that reason, a complete balance sheet of the insect meal sector had to be included in the model for the production of this scenario. There are more net exporters than net importers of ITM. In the camp of the net importers Vietnam, India, Indonesia, LDCs of Asia, Egypt, Norway and Chile are the main one. The main exporters are European Union, USA, China and Africa (excluding Egypt). 
More generally, the differential impacts on prices and production in different countries affects the trade flows (Table 6). African and European imports of meat increase. Oilseed imports decrease in all regions except for Europe and protein meal imports (incl. ITM) increase everywhere except in Oceania and North America.

\section{Food security implications}

Food security is a multifaceted concept involving stable physical availability, physical and economic access and utilisation of food. There are consequently many indicators related to the different dimension of food security. In the following, we focus on food expenditure, as well as calorie consumption in developing countries.

Figure 3 illustrates the distribution of per capita food expenditure impacts across countries in different income groups for the three scenarios. All countries experience lower food prices and the largest impacts occur in Scen1, implying a positive impact on food security. However, there is no relationship between the income status of the country and the food price impact. The median impact in the three scenarios is $-2.1,-1.1$ and $-0.6 \%$, respectively. As the upper panel shows, lower expenditure on animal products contributes less than proportionally to the total change in each of the income groups. The lower food prices in the scenarios lead to a modest changes in per capita calorie and protein consumption, with most countries experiencing a small increase in intake (less than 1\% compared to the baseline). ${ }^{10}$

\section{Carbon footprint}

The impact of GHG emissions from agriculture in the scenarios depends on the global crop and livestock production and land use changes caused by the introduction of this novel source of feed proteins. ${ }^{11}$ In addition, the impact on total agricultural GHG emissions depends on the emissions of the insects themselves during the production process. As it turns out, GHG emission estimates from BSF farming vary largely between studies in the bioconversion literature. For BSFs, Parodi et al. (2020) report an emission coefficient of $17 \pm 8.6 \mathrm{~g}$ carbon dioxide equivalents $\left(\mathrm{CO}_{2}\right.$-eq $)$ per kg of dry larvae. This estimate is, reportedly, twice as large as the one in Ermolaev et al. (2019), half as large as

\footnotetext{
${ }^{10}$ The nutrition impact calculations are based on the FAOSTAT Food Balance Sheets.

${ }^{11}$ The GHG emission impact calculations for agricultural commodities other than insects are based on the GLOBIOM database.
}

Table 6. Import impacts in 2030 in Scen2. Percentage difference between scenario and baseline values.

\begin{tabular}{|c|c|c|c|c|c|c|c|}
\hline & World & Africa & Asia Pacific & Europe & Latin America & North America & Oceania \\
\hline \multicolumn{8}{|l|}{ Meat } \\
\hline Sheep & -1.0 & 6.2 & -2.4 & 1.5 & 2.2 & 0.1 & 0.2 \\
\hline Beef and veal & 0.5 & 2.9 & 0.2 & 1.4 & 1.7 & -1.0 & -0.6 \\
\hline Pork & -1.0 & 1.9 & -2.5 & 2.9 & -0.5 & -1.2 & -1.7 \\
\hline Poultry & 3.7 & 5.8 & 2.6 & 4.5 & 3.2 & 9.1 & 2.1 \\
\hline \multicolumn{8}{|l|}{ Dairy } \\
\hline Cheese & -0.4 & 2.0 & 0.2 & 1.0 & -4.3 & -8.0 & 0.0 \\
\hline Skim milk powder & -0.3 & -0.3 & -0.3 & 0.4 & -0.7 & 0.0 & -0.1 \\
\hline Whole milk powder & 0.1 & 0.1 & 0.4 & 0.7 & -0.9 & 0.0 & 0.0 \\
\hline Butter & -0.7 & 0.2 & -0.9 & 1.3 & -6.1 & -7.4 & 0.0 \\
\hline \multicolumn{8}{|l|}{ Grains and oilseeds } \\
\hline Wheat & 1.3 & 0.3 & 2.6 & -1.2 & 0.5 & -3.4 & -2.8 \\
\hline Maize & 0.4 & 0.8 & 0.3 & -1.2 & 0.8 & 1.2 & -10.8 \\
\hline Other coarse grains & 0.0 & 4.7 & 0.8 & 0.0 & -15.7 & -11.4 & 3.0 \\
\hline Rice & 0.4 & 0.0 & 1.6 & -0.8 & -2.3 & -0.9 & 0.0 \\
\hline Soybean & -2.7 & -1.5 & -3.5 & 2.2 & -1.9 & -0.6 & -6.4 \\
\hline Other oilseeds & -1.9 & 2.1 & -2.7 & 2.5 & -1.7 & -9.0 & -0.2 \\
\hline \multicolumn{8}{|l|}{ Biofuels } \\
\hline Biodiesel & -1.4 & 0.0 & 8.7 & -2.0 & 0.0 & -1.0 & 14.4 \\
\hline Ethanol & 0.4 & 0.0 & 2.3 & -0.8 & -1.5 & 0.4 & 1.0 \\
\hline \multicolumn{8}{|c|}{ Other processed products } \\
\hline Protein meal & -3.5 & -10.0 & -5.7 & -1.9 & -4.8 & 21.6 & 2.9 \\
\hline Vegetable oil & -1.2 & -0.7 & -2.4 & 0.6 & -1.2 & 7.1 & -6.0 \\
\hline Sugar & 0.3 & 0.3 & 0.4 & 0.2 & -1.2 & -0.5 & 0.5 \\
\hline
\end{tabular}




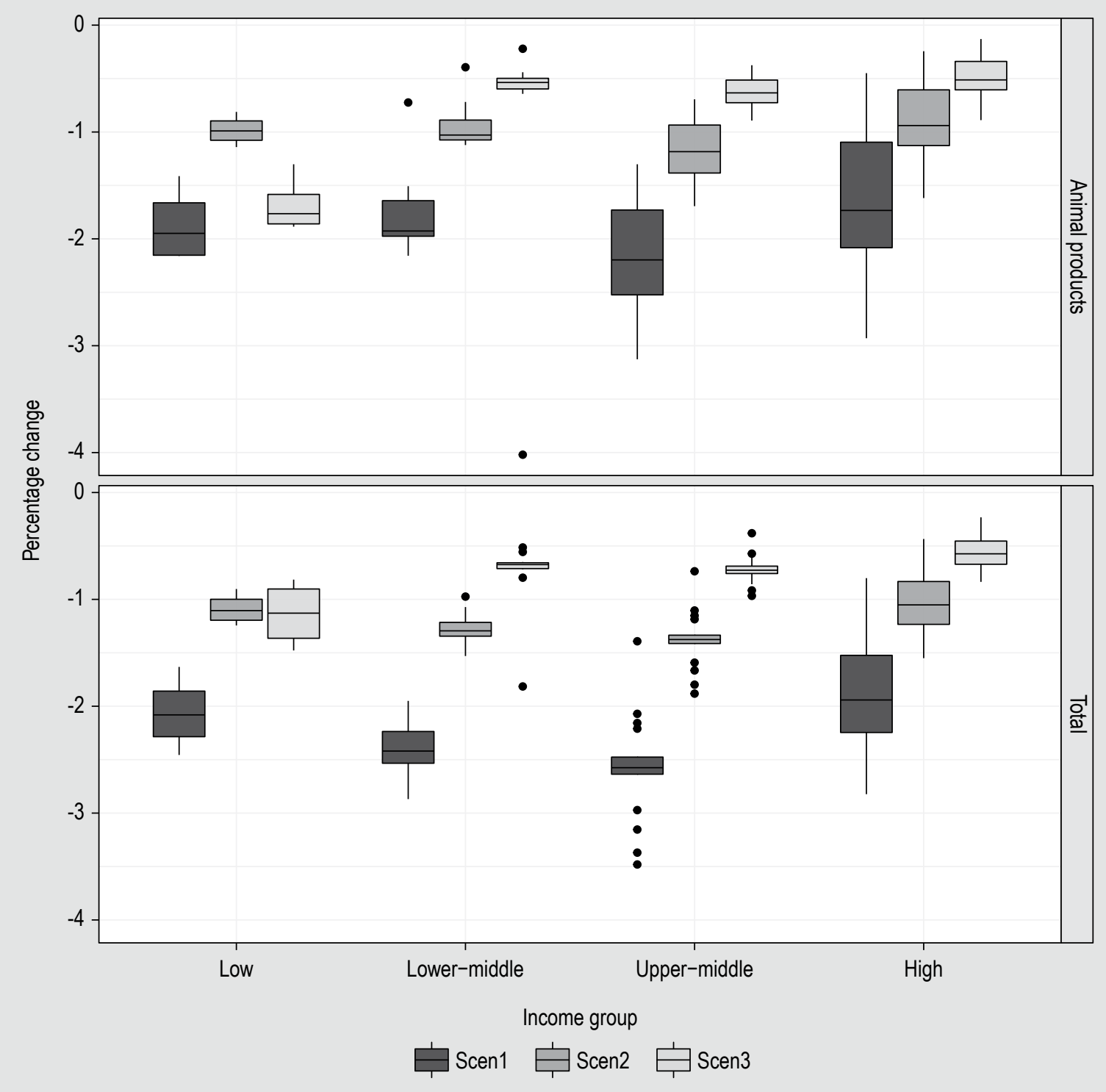

Figure 3. Per capita food expenditure impact in 2030. Percentage difference between scenario and baseline values.

the one in Mertenat et al. (2019) and six times as large as the one in Pang et al. (2020). Nonetheless, even the largest of these emission coefficients are significantly lower than conventional livestock production. Specifically, in the model database, the $2020 \mathrm{EU}$ GHG emission coefficients for beef, pork, poultry and sheep are 12.9, 2.0, 0.6 and $24.4 \mathrm{~kg} \mathrm{CO}_{2}$ eq per kg output, respectively.

We base our insect emission calculations on the estimates from Parodi et al. (2020) and do not include indirect GHG emissions in the calculations. The reason is that indirect emissions are not included in the emission coefficients for conventional livestock or crops. However, Mertenat et al. (2019) report that the inclusion of indirect emission related to electricity consumption in the production process increases the GHG emissions by a factor of 1.8. This, of course, is strongly influenced by type of energy used i.e. whether it derives from renewables or conventional sources. However, direct insect GHG emissions are low in comparison to conventional livestock, so that it does not have a large effect on the results. For example, with these assumptions, the emissions from one $\mathrm{kg}$ of poultry produced in the EU in 2020 are almost 40 times higher than emissions from one $\mathrm{kg}$ of BSF larvae production.

Less intensive crop production, more forest and pasture area and lower sheep production contribute to lower GHG emissions from agriculture in each of the scenarios (Table 7). Although production of livestock increases, the additional emissions do not outweigh the reductions resulting from land use changes, so the net result is a small decrease in global agricultural GHG emissions over the outlook period 2020-2030. 
Table 7. GHG emission impacts ( $\mathrm{CO}_{2}$ equivalents) by type and region. Cumulated difference between scenario and baseline values, million tonnes and percentage of baseline total, 2020-2030.

\begin{tabular}{|c|c|c|c|c|c|c|c|c|c|}
\hline & \multicolumn{3}{|l|}{ Scen1 } & \multicolumn{3}{|l|}{ Scen2 } & \multicolumn{3}{|l|}{ Scen3 } \\
\hline & Total & AGRI & LULUCF$^{1}$ & Total & AGRI & LULUCF & Total & AGRI & LULUCF \\
\hline \multicolumn{10}{|l|}{ World } \\
\hline Difference & -466.50 & 169.30 & -635.70 & -231.60 & 93.20 & -324.80 & -132.00 & 25.60 & -157.50 \\
\hline Percentage & -0.49 & 0.18 & -0.67 & -0.24 & 0.10 & -0.34 & -0.14 & 0.03 & -0.17 \\
\hline \multicolumn{10}{|l|}{ Africa } \\
\hline Difference & -54.30 & -21.80 & -32.50 & -27.70 & -10.90 & -16.80 & -38.40 & -30.70 & -7.70 \\
\hline Percentage & -0.26 & -0.10 & -0.15 & -0.13 & -0.05 & -0.08 & -0.18 & -0.15 & -0.04 \\
\hline \multicolumn{10}{|l|}{ Asia Pacific } \\
\hline Difference & -72.60 & 51.20 & -123.70 & -30.00 & 32.30 & -62.30 & -11.70 & 19.40 & -31.10 \\
\hline Percentage & -0.15 & 0.11 & -0.26 & -0.06 & 0.07 & -0.13 & -0.02 & 0.04 & -0.07 \\
\hline \multicolumn{10}{|l|}{ Europe } \\
\hline Difference & -31.60 & 16.70 & -48.30 & -15.50 & 9.60 & -25.10 & -8.30 & 4.20 & -12.60 \\
\hline Percentage & -1.90 & 1.01 & -2.91 & -0.93 & 0.58 & -1.51 & -0.50 & 0.25 & -0.76 \\
\hline \multicolumn{10}{|l|}{ Latin America } \\
\hline Difference & -161.10 & 106.40 & -267.50 & -83.40 & 53.40 & -136.80 & -37.30 & 27.90 & -65.20 \\
\hline Percentage & -0.98 & 0.65 & -1.63 & -0.51 & 0.32 & -0.83 & -0.23 & 0.17 & -0.40 \\
\hline \multicolumn{10}{|l|}{ North America } \\
\hline Difference & -78.00 & 7.30 & -85.20 & -38.10 & 3.80 & -41.90 & -17.60 & 2.50 & -20.10 \\
\hline Percentage & -1.28 & 0.12 & -1.40 & -0.62 & 0.06 & -0.69 & -0.29 & 0.04 & -0.33 \\
\hline \multicolumn{10}{|l|}{ Oceania } \\
\hline Difference & -69.00 & 9.50 & -78.50 & -36.90 & 4.90 & -41.70 & -18.70 & 2.20 & -20.90 \\
\hline Percentage & -2.49 & 0.34 & -2.84 & -1.33 & 0.18 & -1.51 & -0.67 & 0.08 & -0.75 \\
\hline
\end{tabular}

The total impact in Scen1 corresponds to a cumulative decrease in $\mathrm{GHG}$ emissions (in $\mathrm{CO}_{2}$ equivalents) of around $0.5 \%$, as compared to the baseline. Emissions related to agricultural production (denoted 'AGRI' in the table) go up in all regions except for Africa, where emissions are reduced as domestic livestock production is replaced by imports. Not surprisingly, the largest contributing region to the emission changes is Latin America, which is the top soybeans producing region. It is the region where agricultural emissions increase the most due to additional livestock production, but also the region where land use changes lead to the largest reduction in GHG emissions.

\section{Discussion}

The insect farming industry is expanding and there seems to be an abundance of food waste to support it. Even if the UN SDG 12.3 of halving per capita global food waste at the retail and consumer level is achieved, there remains large quantities of food waste available for insect feed. Moreover, insect farming could play an important role in attaining SDG 12.5 of substantially reducing waste generation through recycling. One question that arises is what would happen if SDG 12.3 was achieved and food waste consequently became scarcer? The remaining food waste would most likely become more expensive to collect and perhaps ITM would only be used in aquaculture where it would attain a premium price compared to oilmeals due to its nutritional composition, which is similar to fishmeal.

More generally, the question is whether the costs of collecting and processing the food waste into a form that is suitable for insect production are low enough for it to make sense economically on a large industrial scale. In the literature on insect farming, or more generally on food waste valorisation or upcycling, there is surprisingly little discussion of this issue. These studies tend to take an experimental approach and even the life cycle analyses focus on quantities and environmental impacts without any mentioning of costs and revenues of the different alternatives. There is, however, a separate literature on waste management that analyses the costs of managing different types of waste. For example, Hogg et al. (2003) report costs of landfill and incineration at EUR 55 and 90 per tonne municipal solid waste (MSW), respectively. The costs of separate collection and composting of biodegradable 
waste is estimated to be in the EUR 35-75 per tonne range. Note that these figures are based on waste management practices in place already in the EU and are partly the result of regulatory policies. Note also that existing insect farms, producing on an industrial scale, typically rely on inexpensive food waste. Some use consumer waste whereas others are built near food processing plants to reduce insect feed costs (Fowles and Nansen, 2020). This is a mutual benefit for both the food processing plants and insect farming industry, who both want to promote a socially and environmentally suitable production.

The analysis presented shows that an expansion of the insect feed industry could have a large impact on the price of oilseed and protein meals. Specifically, utilising $50 \%$ of the available food waste leads to declines of 17 , 7 and $28 \%$ in the projected world price of protein meal, vegetable oils and fishmeal, respectively. These, are the price changes needed to rebalance the global markets in the Aglink-Cosimo model. In this scenario, oilseed prices are reduced by roughly $10 \%$ and 4 million hectares of land are converted from oilseed production to other crops and pasture. This leads to lower land prices, taking 1 million hectares of marginal land out of agricultural production. So the addition of ITM and ITL to the current agricultural commodity markets leads to large market adjustments, especially when taking into account that they do not directly compete for agricultural resources. In that sense, the $18 \%$ price reduction of oilseed meal seems in line with a $10 \%$ reduction in oilseed prices.

An important finding is that a large expansion of the ITM industry does not lead to a large reduction in GHG emissions. GHG emission reductions from agricultural land use change are sufficiently high to offset the additional GHG emissions from crop and animal production in all scenarios, so that the net result is a marginal decrease in GHG emissions. It is somewhat surprising that land use changes offset the higher supply of animal products resulting from the additional supply of feed proteins, which leads to lower feed costs. However, it confirms that recycling of waste is indeed a sustainable practice (c.f. SDGs 12.3 and 12.5). When recycled food waste goes back into the food system as feed, it will lead to more food being produced, but the lower crop production intensities and marginal expansion of forest area will lead to slightly lower GHG emissions. That being said, the introduction of a large scale ITM feed industry based on recycled food waste will not solve the climate crisis by itself.

There are several caveats that deserve mentioning. First, in the analysis the insect industry is considered to be a price taker and is assumed to utilise 100, 50 or $21 \%$ of all available food waste, regardless the resulting protein meal price (which declines by 31,18 or $9 \%$, respectively, in the three scenarios). Would the industry actually be able to cover their costs at these prices? This is not an easy question to answer in the absence of a mature insect industry. In relation to this, we are not considering a second by-product from ITM production called insect dejecta or frass. This is essentially manure from insect larvae, which has the potential to be upcycled to a valuable fertilising product. In the future, with a lower fossil fuel supply due to concerns over climate change from GHG emissions, revenues from insect farming could be strongly dependent on this by-product and it might even affect the fertiliser industry to some degree. A final caveat relates to the other insect by-product that we actually do include in the analysis, namely ITL. We did not consider how the additional oil supply would potentially affect the biofuel mandates in biofuel producing countries. We leave these issues for future research.

\section{Supplementary material}

Supplementary material can be found online at https://doi. org/10.3920/JIFF2021.0007.

Supplementary Material S1. Technical annex.

\section{Conflict of interest}

The authors declare no conflict of interest.

\section{References}

Araujo Enciso, S.R., Perez Dominguez, I., Santini, F. and Helaine, S., 2015. Documentation of the European Commission's EU module of the Aglink-Cosimo modelling system. EUR - Scientific and Technical Research Report, EC, Brussels, Belgium. https://doi. org/10.2791/675854

Banks, I.J., Gibson, W.T. and Cameron, M.M., 2014. Growth rates of black soldier fly larvae fed on fresh human faeces and their implication for improving sanitation. Tropical Medicine \& International Health 19: 14-22.

Barbi, S., Macavei, L.I., Fuso, A., Luparelli, A.V., Caligiani, A., Ferrari, A.M., Maistrello, L. and Montorsi, M., 2020. Valorization of seasonal agri-food leftovers through insects. Science of the Total Environment 709: 136209.

Barragan-Fonseca, K.B., Dicke, M. and Van Loon, J.J., 2017. Nutritional value of the black soldier fly (Hermetia illucens $\mathrm{L}$.) and its suitability as animal feed - a review. Journal of Insects as Food and Feed 3: 105-120.

Belghit, I., Liland, N.S., Waagbø, R., Biancarosa, I., Pelusio, N., Li, Y., Krogdahl, Å. and Lock, E.-J., 2018. Potential of insect-based diets for Atlantic salmon (Salmo salar). Aquaculture 491: 72-81.

Caldeira, C., De Laurentiis, V., Corrado, S., Van Holsteijn, F. and Sala, S., 2019. Quantification of food waste per product group along the food supply chain in the European Union: a mass flow analysis. Resources, Conservation and Recycling 149: 479-488.

Danieli, P.P., Lussiana, C., Gasco, L., Amici, A. and Ronchi, B., 2019. The effects of diet formulation on the yield, proximate composition, and fatty acid profile of the black soldier fly (Hermetia illucens L.) prepupae intended for animal feed. Animals 9: 178. 
Dicke, M., 2018. Insects as feed and the sustainable development goals. Journal of Insects as Food and Feed 4: 147-156.

Dobermann, D., Swift, J. and Field, L., 2017. Opportunities and hurdles of edible insects for food and feed. Nutrition Bulletin 42: 293-308.

European Commission (EC), 2001. Regulation (EC) No 999/2001 of the European Parliament and of the Council of 22 May 2001 laying down rules for the prevention, control and eradication of certain transmissible spongiform encephalopathies. Official Journal of the European Communities L 147: 1-40.

European Commission (EC), 2017. Commission Regulation (EU) 2017/893 of 24 May 2017 amending Annexes I and IV to Regulation (EC) No 999/2001 of the European Parliament and of the Council and Annexes X, XIV and XV to Commission Regulation (EU) No $142 / 2011$ as regards the provisions on processed animal protein (Text with EEA relevance). Official Journal of the European Union 138: 92-116.

European Commission (EC), 2018. A sustainable bioeconomy for Europe: strengthening the connection between economy, society and the environment, EC, Brussels, Belgium.

European Commission (EC), 2019. Communication from the Commission - the European Green Deal. EC, Brussels, Belgium.

European Commission (EC), 2020. Farm to fork strategy. For a fair, healthy and environmentally-friendly food system. EC, Brussels, Belgium.

European Food Safety Authority (EFSA) Scientific Committee, 2015. Risk profile related to production and consumption of insects as food and feed. EFSA Journal 13: 4257.

Ermolaev, E., Lalander, C. and Vinnerås, B., 2019. Greenhouse gas emissions from small-scale fly larvae composting with Hermetia illucens. Waste Management 96: 65-74.

Food and Agriculture Organisation (FAO), 2011. Global food losses and food waste - extent, causes and prevention. Study conducted for the International Congress SAVE FOOD! at Interpack2011 Düsseldorf, Germany. FAO, Rome, Italy.

Food and Agriculture Organisation (FAO), 2019. State of food and agriculture 2019. Moving forward on food loss and waste reduction. FAO, Rome, Italy.

Fowles, T.M. and Nansen, C., 2020. Insect-based bioconversion: value from food waste. In: Närvänen, E., Mesiranta, N., Mattila, M. and Heikkinen, A. (eds.) Food waste management, Springer, Berlin, Germany, pp. 321-346.

Ganda, H., Zannou-Boukari, E., Kenis, M., Chrysostome, C. and Mensah, G., 2019. Potentials of animal, crop and agri-food wastes for the production of fly larvae. Journal of Insects as Food and Feed 5: 59-67.

Gariglio, M., Dabbou, S., Biasato, I., Capucchio, M.T., Colombino, E., Hernández, F., Madrid, J., Martínez, S., Gai, F. and Caimi, C., 2019. Nutritional effects of the dietary inclusion of partially defatted Hermetia illucens larva meal in Muscovy duck. Journal of Animal Science and Biotechnology 10: 37.

Govorushko, S., 2019. Global status of insects as food and feed source: a review. Trends in Food Science \& Technology 91: 436-445.
Heuel, M., Sandrock, C., Mathys, A., Gold, M., Zurbrügg, C., Kreuzer, M. and Terranova, M., 2019. Performance of laying hens when replacing soybean cake and oil by insect larval protein meal and fat. EAAP Scientific Series. Vol. 138. Wageningen Academic Publishers, Wageningen, the Netherlands, pp. 83-90.

Hogg, D., Favoino, E., Nielsen, N., Thompson, J., Wood, K., Penschke, A., Economides, D. and Papageorgiou, S., 2003. Economic analysis of options for managing biodegradable municipal waste - final report. Eunomia Research \& Consulting, Bristol, UK.

Iaconisi, V., Marono, S., Parisi, G., Gasco, L., Genovese, L., Maricchiolo, G., Bovera, F. and Piccolo, G., 2017. Dietary inclusion of Tenebrio molitor larvae meal: effects on growth performance and final quality treats of blackspot sea bream (Pagellus bogaraveo). Aquaculture 476: 49-58.

Intergovernmental Panel on Climate Change (IPCC), 2019. Climate change and land. IPCC, Geneva, Switzerland. Available at: https:// www.ipcc.ch/srccl/

International Platform of Insects for Food and Feed (IPIFF), 2019. The European insect sector today: challenges, opportunities and regulatory landscape. IPIFF vision paper on the future of the insect sector towards 2030. IPIFF, Brussels, Belgium.

International Platform of Insects for Food and Feed (IPIFF), 2020. Insects as feed EU legislation - aquaculture, poultry \& pig species. IPIFF, Brussels, Belgium.

Kupferschmidt, K., 2015. Feature: why insects could be the ideal animal feed. Science. https://doi.org/10.1126/science.aad4709

Lähteenmäki-Uutela, A. and Grmelová, N., 2016. European law on insects in food and feed. European Food and Feed Law Review 11: $2-8$.

Li, Q., Zheng, L., Qiu, N., Cai, H., Tomberlin, J.K. and Yu, Z., 2011. Bioconversion of dairy manure by black soldier fly (Diptera: Stratiomyidae) for biodiesel and sugar production. Waste Management 31: 1316-1320.

Lotta, F., 2019. Insects as food: the legal framework. Edible insects in the food sector. Springer, Berlin, Germany, pp. 105-118.

Magalhães, R., Sánchez-López, A., Leal, R.S., Martínez-Llorens, S., Oliva-Teles, A. and Peres, H., 2017. Black soldier fly (Hermetia illucens) pre-pupae meal as a fish meal replacement in diets for European seabass (Dicentrarchus labrax). Aquaculture 476: 79-85.

Makkar, H.P., Tran, G., Heuzé, V. and Ankers, P., 2014. State-of-theart on use of insects as animal feed. Animal Feed Science and Technology 197: 1-33.

Manzano-Agugliaro, F., Sanchez-Muros, M., Barroso, F., MartínezSánchez, A., Rojo, S. and Pérez-Bañón, C., 2012. Insects for biodiesel production. Renewable and Sustainable Energy Reviews 16: 37443753.

Maurer, V., Holinger, M., Amsler, Z., Früh, B., Wohlfahrt, J., Stamer, A. and Leiber, F., 2016. Replacement of soybean cake by Hermetia illucens meal in diets for layers. Journal of Insects as Food and Feed 2: 83-90.

Mertenat, A., Diener, S. and Zurbrügg, C., 2019. Black soldier fly biowaste treatment - assessment of global warming potential. Waste Management 84: 173-181. 
Nguyen, H.C., Liang, S.-H., Chen, S.-S., Su, C.-H., Lin, J.-H. and Chien, C.-C., 2018. Enzymatic production of biodiesel from insect fat using methyl acetate as an acyl acceptor: optimization by using response surface methodology. Energy Conversion and Management 158: 168-175.

Nguyen, T.T., Tomberlin, J.K. and Vanlaerhoven, S., 2015. Ability of black soldier fly (Diptera: Stratiomyidae) larvae to recycle food waste. Environmental Entomology 44: 406-410.

Organisation for Economic Cooperation and Development (OECD), 2015. Aglink-cosimo model documentation. OECD, Paris, France.

Organisation for Economic Cooperation and Development / Food and Agriculture Organisation (OECD/FAO), 2020. Fish - OECD-FAO agricultural outlook 2020-2029. FAO/OECD Publishing, Rome/ Paris, Italy/France.

Oonincx, D.G., Van Broekhoven, S., Van Huis, A. and Van Loon, J.J., 2015. Feed conversion, survival and development, and composition of four insect species on diets composed of food by-products. PLoS ONE 10: e0144601.

Pang, W., Hou, D., Chen, J., Nowar, E.E., Li, Z., Hu, R., Tomberlin, J.K., $\mathrm{Yu}, \mathrm{Z}$., Li, Q. and Wang, S., 2020. Reducing greenhouse gas emissions and enhancing carbon and nitrogen conversion in food wastes by the black soldier fly. Journal of Environmental Management 260: 110066.

Parfitt, J., Barthel, M. and Macnaughton, S., 2010. Food waste within food supply chains: quantification and potential for change to 2050. Philosophical Transactions of the Royal Society B: Biological Sciences 365: 3065-3081.

Parodi, A., De Boer, I.J., Gerrits, W.J., Van Loon, J.J., Heetkamp, M.J., Van Schelt, J., Bolhuis, J.E. and Van Zanten, H.H., 2020. Bioconversion efficiencies, greenhouse gas and ammonia emissions during black soldier fly rearing - a mass balance approach. Journal of Cleaner Production 271: 122488.

Pinotti, L., Giromini, C., Ottoboni, M., Tretola, M. and Marchis, D., 2019. Insects and former foodstuffs for upgrading food waste biomasses/streams to feed ingredients for farm animals. Animal 13: $1365-1375$.

Purschke, B., Scheibelberger, R., Axmann, S., Adler, A. and Jäger, H., 2017. Impact of substrate contamination with mycotoxins, heavy metals and pesticides on the growth performance and composition of black soldier fly larvae (Hermetia illucens) for use in the feed and food value chain. Food Additives \& Contaminants: Part A 34: 1410-1420.

Salomone, R., Saija, G., Mondello, G., Giannetto, A., Fasulo, S. and Savastano, D., 2017. Environmental impact of food waste bioconversion by insects: application of life cycle assessment to process using Hermetia illucens. Journal of Cleaner Production 140: 890-905
Schiavone, A., De Marco, M., Martínez, S., Dabbou, S., Renna, M., Madrid, J., Hernandez, F., Rotolo, L., Costa, P. and Gai, F., 2017. Nutritional value of a partially defatted and a highly defatted black soldier fly larvae (Hermetia illucens L.) meal for broiler chickens: apparent nutrient digestibility, apparent metabolizable energy and apparent ileal amino acid digestibility. Journal of Animal Science and Biotechnology 8: 1-9.

Sealey, W.M., Gaylord, T.G., Barrows, F.T., Tomberlin, J.K., McGuire, M.A., Ross, C. and St-Hilaire, S., 2011. Sensory analysis of rainbow trout, Oncorhynchus mykiss, fed enriched black soldier fly prepupae, Hermetia illucens. Journal of the World Aquaculture Society 42: 34-45.

St-Hilaire, S., Cranfill, K., McGuire, M.A., Mosley, E.E., Tomberlin, J.K., Newton, L., Sealey, W., Sheppard, C. and Irving, S., 2007. Fish offal recycling by the black soldier fly produces a foodstuff high in omega-3 fatty acids. Journal of the World Aquaculture Society 38: 309-313.

Stamer, A., 2015. Insect proteins - a new source for animal feed: the use of insect larvae to recycle food waste in high-quality protein for livestock and aquaculture feeds is held back largely owing to regulatory hurdles. EMBO Reports 16: 676-680.

Tao, J. and Li, Y.O., 2018. Edible insects as a means to address global malnutrition and food insecurity issues. Food Quality and Safety 2: 17-26.

United Nations (UN), 2015. Transforming our world: the 2030 agenda for Sustainable Development. UN Publishing, New York, NY, USA. Available at: https://sdgs.un.org/2030agenda

United Nations (UN), 2019. World population prospects 2019: highlights. Department of Economic and Social Affairs, Population Division, UN, New York, NY, USA.

Van Broekhoven, S., Oonincx, D.G., Van Huis, A. and Van Loon, J.J., 2015. Growth performance and feed conversion efficiency of three edible mealworm species (Coleoptera: Tenebrionidae) on diets composed of organic by-products. Journal of Insect Physiology 73: 1-10.

Veldkamp, T. and Bosch, G., 2015. Insects: a protein-rich feed ingredient in pig and poultry diets. Animal Frontiers 5: 45-50.

Veldkamp, T., Van Duinkerken, G., Van Huis, A., Lakemond, C., Ottevanger, E., Bosch, G. and Van Boekel, T., 2012. Insects as a sustainable feed ingredient in pig and poultry diets: a feasibility study. Wageningen UR Livestock Research, Lelystad, the Netherlands.

Wang, H., ur Rehman, K., Liu, X., Yang, Q., Zheng, L., Li, W., Cai, M., Li, Q., Zhang, J. and Yu, Z., 2017. Insect biorefinery: a green approach for conversion of crop residues into biodiesel and protein. Biotechnology for Biofuels 10: 304.

Zheng, L., Hou, Y., Li, W., Yang, S., Li, Q. and Yu, Z., 2012. Biodiesel production from rice straw and restaurant waste employing black soldier fly assisted by microbes. Energy 47: 225-229. 
